\title{
Investigation of Social Studies Curriculum in Regards to Migrant, Refugee, Asylum-Seekers Concepts
}

\author{
Bahadır KILCAN \\ Department of Turkish and Social Science Education, Faculty of Education, University of \\ Gazi, Turkey. ORCID: 0000-0003-0646-1804
}

\section{Ünal ŞIMMŞEK*}

Department of Turkish and Social Science Education, Faculty of Education, University of Aksaray, Turkey. ORCID: 0000-0002-9102-0095

\begin{tabular}{|c|c|}
\hline Article history & This study aims to exhibit the current situation of migrant, refugee, \\
\hline $\begin{array}{l}\text { Received: } \\
22.05 .2020\end{array}$ & $\begin{array}{l}\text { asylum-seekers concepts in Social Studies Curriculum (2018) in Turkey } \\
\text { in detail. This study, in which qualitative research method was applied, }\end{array}$ \\
\hline $\begin{array}{l}\text { Received in revised form: } \\
04.10 .2020\end{array}$ & $\begin{array}{l}\text { used document review for the detailed examination of the social studies } \\
\text { curriculum. It referred to descriptive analysis technique in the analysis of }\end{array}$ \\
\hline $\begin{array}{l}\text { Accepted: } \\
22.10 .2020\end{array}$ & $\begin{array}{l}\text { migrant, refugee, asylum-seekers are not included in the social studies } \\
\text { curriculum at all. The six criteria discussed (special purposes, basic }\end{array}$ \\
\hline Key words: & skills, values, achievements of the social studies curriculum, issues to be \\
\hline $\begin{array}{l}\text { Social Studies Curriculum; } \\
\text { Migrant; } \\
\text { Refugee; } \\
\text { Asylum-Seekers Concepts; } \\
\text { Qualitative Research }\end{array}$ & $\begin{array}{l}\text { considered in the implementation of the curriculum, the structure \& } \\
\text { learning areas of the curriculum), partially found a place directly or } \\
\text { indirectly in the curriculum. However, there is a disproportionate } \\
\text { distribution as seen in the findings. While } 11 \text { out of } 18 \text { values in the } \\
\text { values section, } 4 \text { out of } 7 \text { learning areas can be associated with the } \\
\text { concepts of migrant, refugee, asylum-seekers in a direct or indirect } \\
\text { fashion, merely } 15 \text { out of } 27 \text { skills and only } 15 \text { out of } 131 \text { total } \\
\text { achievements are associated with these concepts. Thereupon, the study } \\
\text { reveals that the number of items, particularly the number of } \\
\text { achievements, is insufficient in terms of concepts discussed whilst } \\
\text { schools treat courses subject and achievement centered. In this respect, } \\
\text { the researcher suggests that the distribution rates of migrant, refugee, } \\
\text { asylum-seekers concepts should be more balanced in the curriculum } \\
\text { amongst the criteria discussed in the study. A learning area for inclusive } \\
\text { education should be created that includes all disadvantaged individuals } \\
\text { directly. Accordingly, special purposes, issues to be considered in the } \\
\text { implementation of the program, values, skills and achievements should } \\
\text { be updated in the social studies curriculum (2018). }\end{array}$ \\
\hline
\end{tabular}

\section{Introduction}

Throughout history, people have left their homeland and searched for a reliable place to survive due to reasons such as war, armed conflict, discrimination, and persecution (Odman,

\footnotetext{
*Correspondency:unalsimsek63@gmail.com
} 
1995; Ünal, 2014; Apak, 2014). These people, whose main purpose is to find a safe living space, are identified as migrants, refugees and asylum-seekers according to the criteria set out in the 1951 Geneva Convention adopted by the United Nations High Commissioner for Refugees (UNHCR). However, these concepts confuse people. UNHCR (2018) defines a migrant as someone who migrates from one place to another, generally in search of better economic opportunities on a voluntary basis, while a refugee as "someone who is a citizen of a country or stateless but unable or unwilling to return to their country of origin or state of residence and unable to benefit from their country's protection owing to a well-founded fear of being persecuted for reasons of race, religion, nationality, membership of a particular social group, or political opinion" (UNHCR, 1951). As is seen, there is a distinct difference between the concepts of migrants and refugees. First and the foremost, while the concept of migrant includes volunteering, the concept of refugee requires imperativeness. On the other hand, asylumseekers are defined as "the person who wants to be accepted as a refugee in a country and awaits the result of their application for refugee status" within the framework of relevant national or international documents. According to the 1951 Geneva Convention, individuals coming from Europe and having the relevant conditions are considered as refugees but individuals from outside Europe, even if they meet the relevant requirements, cannot be in refugee status, they are considered as asylum-seekers. Thus, it would not be wrong to define the asylum-seekers as the status used until the refugee status is approved (UNHCR, 1951; Körükmez \& Südaş, 2015; UNHCR, 2018).

As of the end of 2018, there are 70.8 million forcibly displaced people in the world. There are 25.9 million refugees, 41.3 million individuals as displaced people within their country, and 3.5 million asylum-seekers. That said, Turkey comes first among 10 countries with the highest number of refugees (UNHCR, 2018). Considering the ethical and humanitarian dimensions of the case, Turkey is carrying out its part of the responsibility exceedingly. Turkey is making economic, social, sanitary, cultural and structural reforms in order to support these people while also offering important opportunities and contributions in the field of education (Şimşek, 2019). 1951 Refugee Convention advocated education as a fundamental right for refugees. According to UNHCR education policy commitments, a safe environment and free access to education should be provided, and international-national-local institutions should act in cooperation for an effective refugee education (UNHCR, 2009; 2011). In this context, it would not be wrong to state that the main factor in the education process of refugee students is the services offered to them. In other words, the priority is not the results that include the academic success of the student, but the educational opportunities provided for them (UNHCR, 2011).

According to UNICEF data as of $2019,50 \%$ of Syrians immigrated to Turkey were children in the $0-18$ age range. There were $1.740,000$ children in this age range, and presumably 400,000 of them did not go to school (UNICEF, 2019). It is essential that these school-age children continue their education and this situation requires a solution (Coşkun \& Emin, 2016; Emin, 2016; Erçakır-Kozan, 2019; Istanbul Bilgi University, 2015; Kılcan, Çepni \& Kılınç, 2017; MEB, 2014; Sağlam \& Kanbur, 2017; UNICEF, 2015). Therefore, it is important that not only all school stakeholders should show positive attitudes in the process of inclusion of these students in educational environments (Celep, 2000; Köse, Bülbül \& Uluman; 2019; Özgüven, 2011), but also important duties fall to school administrators, teachers, students, other staff working in the school and also to families of students. Although many of these tasks seem to be on the shoulders of people within the school climate, curriculums taught in schools also have an important role that cannot be ignored. This situation reveals the importance of the curriculum studied in schools. Otherwise, teachers who are practitioners of the curriculum may not achieve the expected results (Şimşek, 2019; Şimşek \& Kılcan, 2019). 
Almost everybody accepts the importance of the fact that students who try to stay healthy in all aspects after leaving their own countries should feel love, loyalty and belonging to Turkey and be able to hold on to life again. In Turkey, social studies is the course that owns the mission to cultivate good citizens through educational institutions by including elements mentioned above. Social studies differs from other courses by aspiring to raise good citizens in the country or in the environment (Demirezen \& Akhan, 2016, Şimşek, 2019) and also to deliver different cultural, traditional, racial, linguistic and religious elements in the world without allowing for discrimination in students in classrooms (Ellies, 2007) while trying to prepare students for life in line with their goals. The social studies course aims to socialize individuals and make them effective citizens who are beneficial to the society and integrated with the society, and tries to convey basic skills, values and behaviors to the student in line with these purposes. Considering that the way to raise effective, good, responsible, productive, respectful and patriotic individuals is through the social studies course, the active continuation of the social studies course in the education integration processes of immigrants, refugees and asylum seekers will make the importance of students' success better understood (Safran, 2011). In addition, the fact that the course aims at unity and integrity against social exclusion with the values contained in the course (Y1ldırım, 2017), and adopts universal values in general terms, allows it to embrace the whole world indiscriminatingly. Bayram (2019) in his research with social studies teachers, revealed the view that the disadvantaged groups of immigrant students in the same educational environment as other students can contribute to the development of social skills of all students in social studies course. In addition, with the understanding of inclusive education that sees differences as wealth, it is thought that students in immigrant and other disadvantaged groups will improve both their academic and social skills in social studies course (Şimşek \& Kılcan, 2019). Furthermore, it is known that millions of people from different countries have emigrated to Turkey in recent years. Among these individuals, there are children of school age. One of the important factors in their educational integration process is their teaching curriculum. In this context this study was carried out in order to reveal the current situation of migrant, refugee, asylum-seekers concepts in the Social Studies Curriculum (2018) in Turkey based on the relative differences of the social studies course. For this purpose, the researcher evaluated the curriculum regarding the extent to which it addresses migrants, refugees, and asylum-seekers. At this point, the sub-problems below are examined.

(1) How are the subjects of migrant, refugee, asylum-seekers included on the section of special purposes in the social studies curriculum (2018)?

(2) How are the concepts of migrant, refugee, asylum-seekers included on the section of basic skills in the social studies curriculum (2018)?

(3) How are the concepts of migrant, refugee, asylum-seekers included on the section of values included in the social studies curriculum (2018)?

(4) How are the concepts of migrant, refugee, asylum-seekers included on the section of issues to be considered in the implementation in the social studies curriculum (2018)?

(5) How are the concepts of migrant, refugee, asylum-seekers included on the section of learning areas in the social studies curriculum (2018)?

(6) How are the concepts of migrant, refugee, asylum-seekers included on the section of achievements in the social studies curriculum (2018)?

\section{Method}

This study was carried out in order to examine the inclusiveness level of immigration, refugee and asylum-seekers concepts in the Social Studies Curriculum (2018) approved by the Ministry of National Education in accordance with the qualitative research method and 
document analysis. Qualitative research can be expressed as a process of interpretation by questioning social life and human problems with its own unique methods. In qualitative studies, the researcher tries to explain and understand the concepts, facts and relationships by making use of observation, interview and document review. The researcher determines themes, codes and categories by reading the data one by one. It reveals the results of the research based on these codes and categories obtained (Creswell, 1998; Merriam, 1998). Document analysis involves the analysis of written materials that contain information about the phenomenon or facts intended to be investigated (Yıldırım \& Şimşek, 2013). Document analysis requires the study and interpretation of data to make sense, gain insight, and develop empirical knowledge. Analytical processing in document review includes finding, selecting, evaluating and synthesizing the data contained in the documents (Bowen, 2009). Validity in qualitative research can be expressed as presenting the subject matter within the framework of the main problem objectively (Yıldırım \& Şimşek, 2011). At this point, four basic strategies, namely credibility, transferability, consistency, and verifiability, are considered important in ensuring validity and reliability in qualitative research (Lincoln \& Guba, 1985). Clear and ethical references in the research show that it is conducted in accordance with the principles of consistency and transferability. In addition, the use of the Social Studies Teaching Curriculum (2018) as the main data source in the study shows that it is caried out in accordance with the principle of credibility and verifiability because it reflects the facts.

\section{Collection of Data}

The data source of the research consists of the Ministry of Education approved Social Studies Curriculum (2018). Development plans of this current curriculum is created according to the results of action plans of 64th and 65th Governments, the results of international exams, the scientific researches of the reports prepared by different national and international institutions and organizations, in order to raise future generations in a more equipped way, and to fulfill the necessities of the time and the changing needs of individuals and the society (TTKB, 2017). That is why this curriculum is selected as the data source for this study. In this study, the titles in the Social Studies curriculum (2018) were determined as criteria. In this framework, detailed data were presented and made ready for the analysis process.

\section{Analysis of Data}

In the study themes were determined as the titles in the curriculum. After these were determined as criteria, the in-depth analysis of the curriculum began. The obtained data were given with tables and citations. Also the data obtained were analyzed in accordance with the descriptive analysis approach, which is a data analysis method frequently used in qualitative research. According to Yıldırım and Şimşek (2013), the data obtained in descriptive analysis technique are summarized and interpreted according to previously existing themes. However, the obtained data can be arranged according to the themes put forward by the research questions, or it can be reported using the questions or dimensions resorted to in the interview and observation processes. Direct quotations from the data subject to the research are frequently included in the descriptive analysis. In this context, the results obtained as a result of descriptive analysis were presented in a descriptive way, and the findings section was created by quoting exactly from the social studies curriculum.

\section{Findings}

In this section, the current situation of migrant, refugee, asylum-seekers concepts in the social studies curriculum is discussed in detail. While examining the curriculum of the social 
studies curriculum, the concepts of migration, migrant, refugee, asylum-seekers were the keywords. Special purposes, basic skills, values, issues to be considered in the implementation of the curriculum, the structure and learning areas of the curriculum, achievements, and all the issues that can be directly or indirectly associated with these main topics have been elaborated.

Table 1. Current Situation of Migrant, Refugee, Asylum-Seekers Concepts in The Social Studies Curriculum

\begin{tabular}{llcc}
\hline Criteria & $\begin{array}{c}\text { Number of Items Related to } \\
\text { Migrant, Refugee, Asylum-Seekers } \\
\text { Concepts }\end{array}$ & $\begin{array}{c}\text { Total Number of Items } \\
\text { in the Social Studies } \\
\text { Curriculum }\end{array}$ \\
\hline 1 & Special Purposes & 4 & 18 \\
2 & Basic Skills & 5 & 27 \\
3 & Values & 11 & 18 \\
4 & Issues to Be Considered & 3 & 10 \\
5 & Learning Areas & 4 & 7 \\
6 & Achievements & 15 & 131 \\
\hline
\end{tabular}

In Table 1, the concepts of migrant, refugee, asylum-seekers are handled within the framework of a total of 6 criteria: special purposes, basic skills, values, issues to be considered in the curriculum, learning areas and achievements in the social studies curriculum. Within the scope of these criteria; 4 of the 18 special purposes, 5 of the 27 basic skills, 11 of the 18 values, 3 of the 10 issues to be considered, 4 of the 7 learning areas, 15 of the 131 achievements included in the program can be associated with the concepts of migrant, refugee, and asylum-seekers. In addition, the data in the table above are discussed in detail under the titles below.

Criteria 1. Findings Regarding the Situation of Migrant, Refugee, Asylum-Seekers Concepts On Special Purposes in The Social Studies Curriculum (2018)

Among the special purposes in the curriculum consisting of 18 items, the 4 items below can be directly or indirectly associated with the concepts of migrant, refugee, asylum-seeker. These are; "3. Knowing that the rules of law are binding for everyone and that all individuals and organizations are equal before the law", "14. Believing in the importance of participation, expressing opinions for the solution of personal and social problems", "16. Knowing the importance and ways of being a virtuous person by adopting national, moral values and universal values" and "17. Showing sensitivity to the issues that concern the country and the world" (Ministry of National Education, 2018, p. 8).

Criteria 2. Findings Regarding the Situation of Migrant, Refugee, Asylum-Seekers Concepts On Basic Skills in The Social Studies Curriculum (2018)

There are 27 basic skills in the curriculum. "6. Empathy", "12. Communication", "13. Cooperation", "14. Recognizing stereotypes and prejudices", "23. Social participation skills" (Ministry of National Education, 2018, p. 9) can be directly or indirectly associated with the concepts of migrant, refugee, asylum-seeker.

\section{Criteria 3. Findings Regarding the Situation of Migrant, Refugee, Asylum-Seekers} Concepts On Values in The Social Studies Curriculum (2018)

There are 18 basic skills in the curriculum. "1. Justice", "3. Independence", "4. Peace", "7. Solidarity", "8. Sensitivity", "11. Equality", "12. Freedom”, "13. Respect", “14. Love”, "17. Patriotism", "18. Charity" (Ministry of National Education, 2018, p. 9) values can be directly or indirectly associated with the concepts of migrant, refugee, asylum-seekers. 
Criteria 4. Findings Regarding the Situation of Migrant, Refugee, Asylum-Seekers Concepts On Issues to Be Considered in The Implementation in The Social Studies Curriculum (2018)

The social studies curriculum collected the issues to be considered in the implementation of the curriculum under 10 titles in general. Three of them (2nd, 3rd, 9th Articles) can be directly or indirectly associated with the concepts of migrant, refugee, asylum-seeker. These are; " 2 . Basic principles of Social Studies education such as 'locality, timeliness, interdisciplinary, reflective questioning, past-present-future connection, time-continuity-change and flexibility' should be taken into consideration in the realization of the achievements. In terms of these highlighted principles, the processing times can be changed when necessary.", " 3 . The understanding of 'social studies as social sciences' and 'social studies as reflective thinking' should be given importance. The scientific methods used by social scientists (geographers, historians, etc.) should be sensed to students. By making use of the events inside and outside the school, students should frequently be introduced to real life problems and contradictory situations and they should be encouraged to reflect on the social problems they face.", and "9. Current and controversial issues related to achievements can be brought to class by using different discussion techniques by associating them with problem solving, critical thinking, using evidence, decision making and research skills." (Ministry of National Education, 2018, p. 10).

Criteria 5. Findings Regarding the Situation of Migrant, Refugee, Asylum-Seekers Concepts On Learning Areas in The Social Studies Curriculum (2018)

There are 7 learning areas in the curriculum. These are "1. Individual and Society", "2. Culture and Heritage", "3. People, Places and Environments", "4. Science, Technology and Society", "5. Production, Distribution and Consumption", "6. Effective Citizenship", and "7. Global Connections" (Ministry of National Education, 2018, p. 11-12). "1. Individual and Society", "3. People, Places and Environments", "6. Effective Citizenship", and "7. Global Connections" can be directly or indirectly associated with the concepts of migrant, refugee, asylum-seekers.

Criteria 6. Findings Regarding the Situation of Migrant, Refugee, Asylum-Seekers Concepts On Achievements in The Social Studies Curriculum (2018)

There are 131 achievements in total in the curriculum. Only 15 of them can be directly or indirectly associated with the concepts of migrant, refugee, asylum-seeker. See Table 2 for the distribution of these concepts by grades.

Table 2. Distribution of Achievements by Grades Regarding the Concepts of Migrant, Refugee, Asylum-Seekers in The Social Studies Curriculum

\begin{tabular}{lll}
\hline \multirow{2}{*}{ Grade } & $\begin{array}{l}\text { The Number of Achievements Related to the } \\
\text { Concepts of Migrant, Refugee, Asylum- } \\
\text { Seeker }\end{array}$ & $\begin{array}{l}\text { Total Number of Achievements In The } \\
\text { Social Studies Curriculum }\end{array}$ \\
\hline 4th Grade & 3 & 33 \\
5th Grade & 2 & 33 \\
6th Grade & 4 & 34 \\
7th Grade & 6 & 31 \\
Total & 15 & 131 \\
\hline
\end{tabular}

In Table 2, the concepts of migrant-refugee-asylum-seekers are handled within the framework of the sixth criterion in the social studies curriculum. Accordingly, 3 out of 33 achievements in the 4th grade, 2 out of 33 achievements in the 5th grade, 4 out of 34 achievements in the 6 th grade, 6 out of 31 achievements in the 7th grade, so 15 out of the total 131 achievements in the 
social studies curriculum of all grades can be associated with the concepts of migrant, refugee, asylum-seeker.

In the curriculum, there are 33 achievements for the 4th grade, 33 for the 5 th grade, 34 for the 6th grade and 31 for the 7th grade. Below are achievements directly or indirectly associated with the concepts of migrant, refugee, asylum-seeker. These are:

\section{$4^{\text {th }}$ Grade Achievements Associated with The Concepts of Migrant, Refugee, Asylum- Seeker}

These are "SS.4.1.4. Empathizing with other individuals with different characteristics", "SS.4.1.5. Respecting different characteristics of other individuals", "SS.4.7.4. Respecting different cultures" (Ministry of National Education, 2018, p. 14-16).

\section{$5^{\text {th }}$ Grade Achievements Associated with The Concepts of Migrant, Refugee, Asylum- Seeker}

These are "SS.5.2.4. Analyzing cultural elements' role in coexistence", "SS.5.6.3. Explaining the basic rights and their importance" (Ministry of National Education, 2018, p. 17-19).

\section{$6^{\text {th }}$ Grade Achievements Associated with The Concepts of Migrant, Refugee, Asylum- Seeker}

These are "SS.6.1.2. Analyzing the place and role of social, cultural, and historical connections on social cohesion", "SS.6.1.3. Questioning the prejudices about differences in order to live in harmony in the society", "SS.6.1.4. Participating in activities that support social assistance and solidarity in the formation of social unity", "SS.6.1.5. Defending that solutions to a problem should be based on rights, responsibilities and freedoms" (Ministry of National Education, 2018, p. 20-22).

\section{$7^{\text {th }}$ Grade Achievements Associated with The Concepts of Migrant, Refugee, Asylum- Seeker}

These are "SS.7.1.1. Questioning one's own attitudes and behaviors by analyzing the attitudes and behaviors that affect communication", "SS.7.1.2. Using positive communication ways in individual and social relations", "SS.7.3.3. Discussing the causes and consequences of migration through case studies", "SS.7.7.1. Giving examples from international organizations of which Turkey is a member", "SS.7.7.3. Questioning stereotypes about various cultures", "SS.7.7.4. Developing suggestions for the solution of global problems in groups" (Ministry of National Education, 2018, p. 23-25).

The study shows that the concepts of "migrant, refugee, asylum-seeker" are not directly mentioned within the social studies curriculum (2018) examined in detail. However, the concept of "migration" takes place only in two places in the curriculum. While it is mentioned directly in the achievement subject that is "SS.7.3.3. Discussing the causes and consequences of migration through case studies", it is only mentioned in the explanation part of another achievement subject "SS.7.7.4. Developing suggestions for the solution of global problems in groups" as "Global climate change, natural disasters, hunger, terrorism and migration subjects will be discussed" (Ministry of National Education, 2018). 


\section{Conclusion and Discussion}

In this section, the results of the research have been evaluated within the framework of the current literature. In the research, the concepts of migrant, refugee, asylum-seekers in social studies curriculum were examined within the framework of certain criteria. When the curriculum is first examined, it is seen that the concepts of "migrant, refugee, asylum-seeker" are not directly mentioned. With that being said, apart from these concepts, the concept of "migration" exists solely in two places within the curriculum. After this general analysis, the curriculum was examined in detail within the framework of the determined criteria. These criteria consist of six main topics in the social studies curriculum. When examined according to the first criterion, the special purposes in the curriculum consist of 18 items and 4 of them $\left(3^{\text {rd }}, 14^{\text {th }}, 16^{\text {th }}\right.$, and $17^{\text {th }}$ items $)$ can be directly or indirectly associated with the concepts of migrant, refugee, asylum-seeker. When examined according to the second criterion, the basic skills in the curriculum consist of 27 items and only 5 of them $\left(6^{\text {th }}, 12^{\text {th }}, 13^{\text {th }}, 14^{\text {th }}\right.$, and $23^{\text {rd }}$ items $)$ can be directly or indirectly associated with the concepts of migrant, refugee, asylum-seeker. When examined according to the third criterion, the values in the curriculum consist of 18 items and 11 of them $\left(1^{\text {st }}, 3^{\text {rd }}, 4^{\text {th }}, 7^{\text {th }}, 8^{\text {th }}, 11^{\text {th }}, 12^{\text {th }}, 13^{\text {th }}, 14^{\text {th }}, 17^{\text {th }}\right.$, and $18^{\text {th }}$ values $)$ can be directly or indirectly associated with the concepts of migrant, refugee, asylum-seeker. When examined according to the fourth criterion, the issues that should be considered in implementation in the curriculum consist of 10 items and 3 of them $\left(2^{\text {nd }}, 3^{\text {rd }}\right.$, and $9^{\text {th }}$ items $)$ can be directly or indirectly associated with the concepts of migrant, refugee, asylum-seeker. When examined according to the fifth criterion, the learning areas in the curriculum consist of 7 items and 4 of them $\left(1^{\text {st }}, 3^{\text {rd }}\right.$, $6^{\text {th }}$, and $7^{\text {th }}$ learning areas) can be directly or indirectly associated with the concepts of migrant, refugee, asylum-seeker. Finally, when examined according to the sixth criterion, within the framework of the achievements in the curriculum, 3 of the fourth grades (SS.4.1.4.-SS.4.1.5.SS.4.7.4.), 2 of the fifth grades ( SS.5.2.4.-SS.5.6.3.), 4 of the sixth grades (SS.6.1.2.-SS.6.1.3.SS.6.1.4.-SS.6.1.5.), 6 of the seventh grades (SS.7.1.1.-SS.7.1.2.-SS.7.3.3.-SS.7.7.1.-SS.7.7.3.SS.7.7.4), so 15 out of 131 achievements in total can be directly or indirectly associated with the concepts of migrant, refugee, asylum-seeker. Considering the findings of the research, while the concepts of migrant, refugee, asylum-seekers were not included in the social studies curriculum at all, they were found to be discussed directly or indirectly in the six criteria. However, as seen in the findings, there is a disproportionate distribution. While the number of items that can be associated 11 out of 18 values and 4 out of 7 learning areas is high in some sections, only 5 out of 27 skills and only 15 of 131 total achievements are associated with related concepts. The number of items, in particular the number of achievements, is insufficient considering that the courses are taught in terms of achievement and subject-centered. As a matter of fact, displaced children (migrant, refugee, asylum-seeker) in the disadvantaged groups (IMECE, 2017) need additional lessons in terms of benefiting from education and revealing their potential. The EU has recommended the establishment of support units in schools to sustain the education and development of these students in a qualified manner (European Commission, 2010). The more investments are made to these students in the disadvantaged groups, the higher success rate will get in education. Thusly it will increase the welfare, peace and sustainable growth level of the society (ERG, 2016). At this point, if education system in Turkey which was founded based on equalitarian perspective reflects this equalitarian approach on curriculums in a more inclusive way, it can ensure more productivity of students included in these disadvantaged groups. Indeed, while Stubbs (2008) and UNESCO (2007) counted individuals in the disadvantaged groups among vulnerable groups at the point of access to education, they specifically mentioned migrant and refugee children living in the conflict zone. ERG (2009) stated that the differences of the students should not hinder their access to education, otherwise their chances of realizing their potential will decrease. At this point, 
schools should take into account the educational needs of all students and the society, as well as refugee and asylum-seekers based on cultural diversity (Amthor, \& Roxas, 2016). Considering the needs of the students in disadvantaged groups, the curriculum should be flexible (Tinklin, Riddell \& Wilson, 2004, Şimşek, 2019; Şimşek \& Kilcan, 2019). Comprehensive education advocates stated that if a radical change is not made in existing schools and their curricula, the existing curricula will continue to exclude them, and the goal cannot be achieved (Ainscow, 1998; Jenkinson, 1997).

ERG (2016) reached remarkable results in a study with teachers. In this study, the idea of enabling teacher-student communication and assuming that disadvantaged students are also present in the classroom environment is suggested for flexibility in the curriculum flow. It is pointed out that most of the schools where refugee students attend are lacking adequate funding, qualified curriculum and qualified teachers (Callahan, 2013; Golden et al., 2014; Nash, \& Associates, 2015). In addition to the language problems experienced by refugee students, a difficult curriculum and low performance based on this made it difficult for refugee students to achieve success (Callahan, 2013; Golden et al., 2014; Kardeş \& Akman, 2018; Kiang \& Supple, 2016; Nash \& Associates, 2015; Palaz, Çepni \& Kılcan, 2019). Madziva and Thondhlana (2017) pinpointed the importance of providing inclusive education, identifying various needs of students in different situations, addressing emotional and psychological needs of these students, organizing curricula on these issues, having teachers' increase self-efficacy and support these students' communication with their peers. Bayram (2019) stated that the biggest obstacles to inclusive education involving disadvantaged groups are curriculum, social perception and practices. He listed the solution suggestions of inclusive education to eliminate obstacles in the form of reorganizing the curriculum and course hours, and teachers receiving an effective education before and during the service period. Mutlu and Öztürk (2017) examined the perceptions and practices of knowledge and history teachers towards differentiated teaching and they observed that although teachers had a positive perception of their professional competencies, differentiated classroom teaching practices and curricula were not at a sufficient level. Wubbels, Brok, Veldman and Tartwijk (2006) emphasized the necessity of organizing the curriculum by considering the needs of students with differences in their study. According to Bayram (2019) curriculum of materials to be used in social studies education including local subjects for national boundaries in connection with its content or being able to be differentiated according to the cultural and social characteristics of the students will make the teaching more interesting and integrative for the student. Bearing in mind that social studies is a lesson that conveys gains in social values and skills, this subject has a special importance. Looking at the studies on the subject in general, it is witnessed that despite the fact that the migrant, refugee, asylum-seekers students are included in the educational environment, not knowing how to approach them indicates that the teachers alone lack sufficiency in intercultural interaction, so the idea of making systematic arrangements in teaching curricula is supported highly (Baltac1, 2014; Balkar, et al., 2016; Betancourt et al., 2015; Callahan, 2013; Ellis et al., 2010; Emin, 2016; Er \& Bayındır, 2015; Eroğlu \& Gülcan, 2016; Golden et al., 2014; Kırılmaz \& Öntaş, 2020; Kiang \& Supple, 2016; Nash \& Associates, 2015; Polat \& Rengi, 2014; Rana et al., 2011; Sağlam \& Kanbur, 2017; Sakız, 2016; Şimşek, 2019; Şimşek \& Kılcan, 2019; Taştekin, et al., 2016). In light of these results, social studies curriculum (2018) should embody more inclusive education covering migrant, refugee, asylum-seekers concepts. Subject distribution rates should be more balanced within the criteria discussed in the research. A learning area which includes all disadvantaged individuals can be created. Accordingly, the special purposes, issues that should be considered, values, skills, and achievements of the social studies curriculum can be updated. 


\section{References}

Ainscow, M. (1998). Exploring links between special needs and school improvement. Support for Learning, 13(2), 70-75.

Amthor, R.F \& Roxas, K. (2016). Multicultural education and newcomer youth: Re-Imagining a more inclusive vision for immigrant and refugee students, Educational Studies, 52(2), 155-176.

Apak, H. (2014). Adaptation of the Syrian Immigrants to Urban: A Case Study of Mardin Mukaddime, 5(2), 53-70.

Balkar, B., Şahin, S. \& Işıklı Babahan, N. (2016). Problems confronted by Syrian teachers working at temporary education centers (TECs). Journal of Theory and Practice in Education, 12(6), 1290-1310.

Baltac1, H. (2014). The evaluation of the factors affecting the level of achievement of immigrant students to the opinions of school administrators, teachers, parents and students. Unpublished master's thesis, Near East University, Institute of Educational Sciences, Cyprus.

Bayram, B. (2019). Social studies teachers' perceptions and practices for inclusive education, Master's Thesis, Erciyes University, Institute of Education Sciences, Kayseri.

Betancourt, T. S., Frounfelker, R., Mishra, T., Hussein, A., \& Falzarano, R. (2015). Addressing health disparities in the mental health of refugee children and adolescents through community-based participatory research: A study in 2 communities. American Journal of Public Health, 105(3), 475-482.

Blackwell, D., \& Melzak, S. (2000). Far from the battle but still at war: Troubled refugee children at school. London: The Child Psychotherapy Trust. http://understandingchildhood.net/documents/22Farfromthebattle.pdf from accessed.

United Nations High Commissioner for Refugees (BMMYK) (1951). Mültecileri Korumak [Protecting Refugees] https://www.unhcr.org/cy/wpcontent/uploads/sites/41/2018/05/UNHCR_Brochure_TR.pdf from accessed.

Bowen, G.A. (2009), "Document Analysis as a Qualitative Research Method", Qualitative Research Journal, 9(2), 27-40. https://doi.org/10.3316/QRJ0902027

Callahan, R. M. (2013). The English learner dropout dilemma: Multiple risks and multiple resources. Santa Barbara, CA: California Drop Out Research Project. http://www.cdrp.ucsb.edu/pubs_reports.htm from accessed.

Celep, C. (2000). Ĕgitimde örgütsel adanma ve öğretmenler [Organizational devotion and teachers in education]. Ankara: An1. Creswell, J. W. (1998). Qualitative inquiry and research design: choosing among five traditions. Thousand Oaks, CA: Sage.

Creswell, J. W. (1998). Qualitative inquiry and research design: choosing among five traditions. Thousand Oaks, CA: Sage Publications.

Coşkun, İ. \& Emin, M. N. (2016). Türkiye'deki Suriyelilerin eğitimde yol haritası. Fırsatlar ve zorluklar [Roadmap in training the Syrians in Turkey. Opportunities and challenges]. SETA Foundation for Political, Economic and Social Research: İstanbul. http://file.setav.org/Files/Pdf/20160906135243_turkiyedeki-suriyelilerin-egitimindeyolharitasi-pdf.pdf from accessed.

Demirezen, S., \& Akhan, N. E. (2016). Social studies teachers' views on inclusive practices. Bolu Abant Izzet Baysal Faculty of Education Journal, 16, 1206-1223.

Doğanay, A. (2005). Social studies teaching. C, Öztürk., D, Dilek., (Eds.), Life studies and social studies teaching, (pp.17-47), (5th edition). Ankara: Pegem.

The Education Reform Initiative (ERG) (2009). Right to Education and Rights in Education Evaluation of National Legislation in the Light of International Human Rights 
Documents.http://dspace.ceid.org.tr/xmlui/bitstream/handle/1/79/ekutuphane4.2.3.9.pd f? sequence $=1 \&$ isAllowed $=y$ from accessed.

The Education Reform Initiative (ERG) (2016). Policy proposals to promote inclusive education in Turkey. http://www.egitimreformugirisimi.org/kapsayici-egitimindurumu-ve-oneriler/ from accessed.

Ellies. A. K. (2007). Teaching an learning elementary social studies, (eight edition). USA: Pearson Education.

Ellis, B. H., Lincoln, A. K., Charney, M. E., Ford- Paz, R., Benson, M., \& Strunin, L. (2010). Mental health service utilization of Somali adolescents: Religion, community, and school as gateways to healing. Transcultural Psychiatry, 47(5), 789-811.

Emin, M. N. (2016). Türkiye'deki Suriyeli çocukların eğitimi. Temel eğitim politikaları [Syrian children's education in Turkey. Basic education policies]. SETA Foundation for Political, Economic and Social Research: Istanbul. http://file.setav.org/Files/Pdf/20160309195808_turkiyedeki-suriyeli-cocuklarinegitimipdf.pdf from accessed.

Er, A. R. \& Bayındır, N. (2015). Pedagogical approaches of elementary teachers for primary refugee children. International Journal of Social and Educational Sciences, 2(4), 175185.

Erçakır-Kozan, B. (2019). A case study: Exploring the experiences of educational stakeholders in relation to refugee education at a public school in Mamak, Master Thesis, Middle East Technical University, The Department of Educational Sciences, Ankara.

Eroğlu Ö. B. \& Gülcan, M.G. (2016). Göçle gelen ailelerin ve çocuklarının eğitim sorunları (Mersin Illi Örneği) [Educational problems of migrant families and their children (Mersin Province Example)]. K. Beycioğlu, N. Özer, D. Koşar, İ. Şahin (Ed.), Eğitim Yönetimi Araştırmaları içinde [In Educational Management Studies] (pp. 219-238). Ankara: Pegem.

European Commission, (2010). European Disability Strategy 2010-2020: A Renewed Commitment to a Barrier-Free http://eurlex.europa.eu/LexUriServ/LexUriServ.do?uri=COM:2010:0636:FIN:en:PDF from accessed.

Golden, L., Harris, B., Mercado-Garcia, D., Boyle, A., Le Floch, K. C., \& O’Day, J. (2014). A focused look at schools receiving school improvement grants that have percentages of English language learner students, NCEE Evaluation Brief: NCEE (2014-4014). http://files. eric.ed.gov/fulltext/ED544789.pdf sayfasından erişilmiştir

Hitchock G., \& Hughes, D. (1995). Research and the Teacher: A Qualitative Introduction to School-based Research, Psychology Press.

Istanbul Bilgi University. (2015). Suriyeli mülteci çocukların Türkiye devlet okullarındaki durumu politika ve uygulama önerileri [State policy and practice recommendations Syrian refugees in Turkey's public-school children]. http://cocuk.bilgi.edu.tr/wpcontent/uploads/2015/09/SuriyeliCocuklar-Egitim-Sistemi-Politika-Notu.pdf from accessed.

Jenkinson, J. C. (1997). Mainstreaming or special? Educating students with disabilities. London and Newyork: Routledge Pres.

Kardeş, S. \& Akman, B. (2018). Teachers' views on the education of Syrian refugees. Elementary Education Online, 17(3), 1224-1237.

Kılcan, B., Çepni, O. \& Kılınç, A. C. (2017). Development of the attitude towards refugee students scale. Journal of Human Sciences, 14(2), 1045-1057.

Kırılmaz, M.C. \& Öntaş, T. (2020). Examination of implementing inclusive education towards refugees by elementary school teachers. HAYEF: Journal of Education,17, 51-82. 
Kirılmaz, M.C. (2019). Examination of implementation case of inclusive education towards refugees by elementary school teachers, Master's Thesis, Zonguldak Bulent Ecevit University, Institute of Social Sciences, Zonguldak.

Kiang, L., \& Supple, A. J., (2016). Theoretical perspectives on Asian American youth and families in rural and new immigrant destinations. In L. J. Crockett \& G. Carlo (Eds.), Rural ethnic minority youth and families in the United States (pp. 71-88). New York, NY: Springer International Publishing.

Körükmez, L. \& Südaş, I. (2015). Göçler ülkesi [Land of migrants]. Istanbul: Ayrinti

Köse, N., Bülbül, O. \& Uluman, M. (2019). Investigation attitudes towards refugee students of class teachers' in terms of several variables. Journal of Continuous Vocational Education and Training, 2(1), 16-29.

Lincoln, S., \& Guba, E. G. (2000). Paradigmatic Controversies, Contradictions and Emerging Confluences, in N.K. Denzin, and Y.S. Lincoln (eds.), Handbook of Qualitative Research (2nd ed.), London: Sage.

Madziva, R. \& Thondhlana, J. (2017). Provision of quality education in the context of Syrian refugee children in the UK: Opportunities and challenges, compare: A Journal of Comparative and International Education, 47(6), 942-961.

Merriam, S. (1998). Qualitative research and case study applications in education. San Francisco: Jossey-Bass.

Ministry of Education (2017). Sosyal bilgiler dersi ögretim programı (İlkokul ve Ortaokul 4, 5, 6 ve 7. Siniflar) [Social studies curriculum (Primary and Secondary School 4, 5, 6 and 7th Grades]. http://ttkb.meb.gov.tr from accessed.

Ministry of Education (2018). Sosyal bilgiler dersi ögretim programı [Social studies curriculum].http://mufredat.meb.gov.tr/Dosyalar/201812103847686SOSYAL\%20B\% C4\%B0LG\%C4\%B0LER\%20\%C3\%96\%C4\%9ERET\%C4\%B0M\%20PROGRAMI\% 20.pdf from accessed.

Mourshed, M., Chijioke, C., \& Barber, M. (2007). How the world's most improved school systems keep getting better. McKinsey \& Company website http://mckinseyonsociety.com/downloads/reports/Education/How-the-Worlds-MostImproved-School-Systems-Keep-Getting-Better_Download-version_Final.pdf sayfasından erişilmiştir.

Mutlu, N. \& Öztürk, M. (2017). Teachers' perceptions and applications for differentiated instruction in social studies and history lessons. Trakya Journal of Education, 7(2), 379402.

Nash, \& Associates. (2015). Refugee students' needs assessment survey (Report 2015). https://www.sandiegounified.org/sites/default/files_link/district/files/cyt/Refugee\%20 St udent\%20Needs\%20Assessment\%20Report\%202015\%20San\%20Diego\%20Unified.p $\mathrm{d}$ f. from accessed.

Odman, M.T. (1995). Refugee law. Ankara: Human Rights Center

Özgüven, İ. E. (2011). Bireyi tanıma teknikleri [Individual recognition techniques]. Ankara: Nobel.

Palaz, T., Çepni, O. \& Kılcan, B. (2019). Ortaokul öğrencilerinin mülteci öğrencilere yönelik düşüncelerinin ve tutumlarının belirlenmesi [Secondary school students' opinions and attitudes on refugee students], Turkish Studies, 14(3), 1661-1684.

Patton, M.Q. (1990). Qualitative evaluation and research methods. USA: Sage.

Polat, S. \& Rengi, Ö. (2014). Primary teachers' perception of cultural diversity and intercultural sensitivity. Zeitschrift für die Welt der Türken Journal of World of Turks, 6(3), 135-156. 
Rana, M., Qin, D. B., Bates, L., Luster, T., \& Saltarelli, A. (2011). Factors related to educational resilience among Sudanese unaccompanied minors. Teachers College Record, 113(9), 2080-2114.

Safran, M. (2011). Özel öğretim Yöntemleriyle Sosyal Bilgiler Öğretimi. (2. Baskı) [Social Studies Teaching with Special Teaching Methods.(2. Edition)] Ankara: Pegem A.

Sağlam, H. İ. \& İlksen-Kanbur, N. (2017). Investigation attitudes towards refugee students of class teachers' in terms of several variables. Sakarya University Journal of Education, 7(2), 310-323.

Sakız, H. (2016). Göçmen çocuklar ve okul kültürleri: Bir bütünleştirme önerisi [Immigrant children and school cultures: An integration proposal]. Journal of Migration, 3(1), 6581.

Stubbs, S. (2008). Inclusive education: Where there are few resources, Oslo: The Atlas Alliance.

Şimşek, Ü. (2019). Comparison of social studies teachers' attitudes and self-efficacy towards inclusive education and their views on classroom practices, Doctoral Thesis (Ph.D), Gazi University, Institute of Education Sciences, Ankara.

Şimşek, Ü. \& Kılcan, B. (2019). Inclusive education through the eyes of teachers. International Journal of Psychology and Education Studies (IJPES), 6(3), 27-37.

UNICEF \& UNESCO. (2007). A human rights-based approach to education for all. Ankara: United Nations.

UNICEF (2019). Turkey Humanitarian Situation Report No. 36, https://www.unicefturk.org/public/uploads/files/UNICEF\%20Turkey\%20Humanitaria n\%20Situation\%20Report\%20No.\%2036\%20-\%20End-Year\%202019.pdf from accessed.

United Nations High Commission for Refugees (UNHCR) (2009). Global trends: Refugees, asylum-seekers, returnees, internally displaced and stateless persons. https://www.unhcr.org/4c11f0be9.pdf from accessed.

United Nations High Commission for Refugees (UNHCR) (2011). Global trends: A year ofcrises.https://www.unhcr.org/statistics/country/4fd6f87f9/unhcr-global-trends2011.html from accessed.

United Nations High Commission for Refugees (UNHCR) (2018). Refugees and immigrants?https://www.unhcr.org/cy/wpcontent/uploads/sites/41/2018/02/UNHCR_ Refugee_or_Migrant_TR.pdf from accessed.

United Nations High Commissioner For Refugees (UNHCR) (1951). Protecting Refugees. https://www.unhcr.org/cy/wpcontent/uploads/sites/41/2018/05/UNHCR_Brochure_T R.pdf from accessed.

Ünal, S. (2014). Turkey's unexpected guests: Foreign immigrants and refugees experience in the context of "other". Zeitschriftfürdie Welt der Türken/ Journal of World of Turks, 6(3), 65-89.

Taştekin, E., Bozkurt Yükçü, S., İzoğlu, A., Güngör, İ., Işık Uslu, E. A. \& Demircioğlu, H. (2016). Investigation of pre-school teachers' perceptions and attitudes towards multicultural education. Hacettepe University Graduate School of Educational Sciences The Journal of Educational Research, 2(1), 1-20.

Tinklin, T., Riddell, S., \& Wilson, A. (2004). Policy and provision for disabled students in higher education in Scotland and England: The current state of play. Studies in Higher Education, 29(5), 637-657.

Board of Education and Discipline [TTKB] (2017). Social studies lesson curriculum (Primary and Secondary School 4, 5, 6 and 7th Grades). http://ttkb.meb.gov.tr from accessed. 
Wubbels, T., Brok, P.J., den, Veldman, I., \& Tartwijk, J. (2006). Teacher interpersonal competence for Dutch secondary multicultural classrooms. Teachers and Teaching: Theory and Practice, 12, 407-433.

Yıldırım, A. \& Şimşek, H. (2013). Sosyal bilimlerde nitel araştırma yöntemleri [Qualitative research methods in the social sciences]. Ankara: Seckin.

Yıldırım, E. (2017). An investigation into the asylum seekers oriented inclusive education in social studies classes, Doctoral Thesis (Ph.D), Gazi University, Institute of Education Sciences, Ankara. 